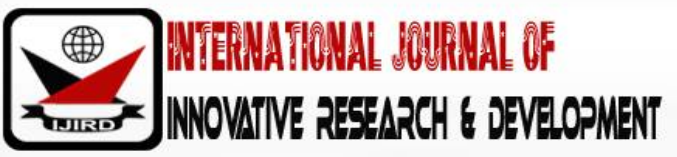

ISSN 2278 - 0211 (Online)

\section{Child Labour: Effects of the Concurrent Roles of Working and Studying on the Academic Life of Basic School Pupils in Ahafo Kenyasi, Ghana}

\begin{tabular}{c|}
\hline Emmanuel Adu Appiah \\
Tutor, Department of Social Sciences \\
OLA Girls Senior High School, Kenyasi , Ghana \\
Prince Kwame Affum \\
Assistant Counsellor, Department of Counselling Unit, \\
University of Energy and Natural Resources, Ghana
\end{tabular}

\begin{abstract}
:
The aim of this study was to examine the effects of working and studying concurrently on the academic life of basic school pupils in Ahafo Kenyasi. The study adopted the qualitative approach of research using the case study design. Snowball sampling procedure was used to sample 35 basic school pupils who were involved in child labour and convenience sampling technique was used to select 15 teachers in basic schools. Findings of the study revealed hawking; market trade and petty trading as major forms of work activities that basic school pupils in Ahafo Kenyasi were engaged in. The study also revealed that working and studying concurrently is mainly caused by low family income and large family size. It was concluded among other things that working and studying concurrently causes children to feel fatigue, tiredness and poor concentration, limited time for studying and doing homework, absenteeism and regular class repetitions. It was also recommended among other things that parents must be made aware of the relevance of their children's education and dangers in working and studying concurrently through the efforts of Parent Teacher Association and the District Education Directorate.
\end{abstract}

Keywords: Child labour, concurrent roles, working and studying, academic life

\section{Introduction}

Child labour can be described as one of the global child issues which seems not to go away completely although significant strides have been made by countries and international organizations either separately or together and by individuals and institutions. Childhood is a phase of life when a child is free from all tension, fun loving, playful and learns new things, and is also the sweetheart of the family. However, not all children go through the beautiful stage of childhood; most children go through this period in full tension, burdened and are made to work to help in maintaining their families (Orazem \& Gunnarsson, 2004).

Child labour is a social problem associated with the rise of industrial production and capitalism. It appeared in earlier ages in agricultural societies, but during the industrial revolution of the 18th century in Great Britain it was especially conspicuous and began to be opposed. It was one of the biggest scandals of the 19th century, spreading to other countries as they industrialized (Santrock, 2003).

This issue of child labour is not confined only to the industrialized world. Child labour is a widespread problem in developing countries as well. When children under age work, their labour time disrupts their schooling and in majority of cases prevent them from attending school altogether. According to the International Labor Organization (ILO) (2010), child labor affects 215 million minors worldwide. Within recent years, a decreasing tendency in this figure has been observed, especially in areas of Asia, the Pacific, Latin America, and the Caribbean. The greatest decrease occurred in the most dangerous work (related to the worse forms of child labor) and among female children and youth. However, the number of 15- to 17-year-old youth laborers has significantly increased within the last four years (from 52 to 62 million worldwide) (Holgadoa, Maya-Jariegoa, Ramosa, Palacio, Oviedo- Trespalaciosc, Romero-Mendozab, \& Amarb, 2014). Bhalotra and Heady (2003) posit that the incidence of child labour is higher in Africa than anywhere else in the world and this has been fueled by factors like economic decline, war, famine and HIV/ AIDS. Virtually all working children in Africa are engaged by their own households with low income level being the biggest reason. Also, combining work and school is more common in Africa.

From the Ghana Living Standard Survey (GLSS) report, proportion of working children in rural areas was 38.3\%, $43.8 \%$ in rural savannah, $38.3 \%$ in rural forest and $21.9 \%$ in rural coastal areas. The proportion of children engaged in economic activities among the 15-17 years age group was $42.9 \%$ while that of the 5-7 years age group was $9.9 \%$. Children who combined work and school constituted $26.3 \%$ while their non-schoolina counterparts constituted $41.6 \%$. Of the 
children 5-17 years who participated in economic activity, 76.4 percent were involved in child labour, out of which 49.7 percent participated in hazardous work (Ghana Statistical Service, 2014).

The above statistics indicate the intensity of child labour and the need to address it in order to eliminate its adverse effects on human capital development and the future growth potential of developing countries.

Working and studying at the same time is a complex phenomenon, mostly common in rural areas of African and Asian countries. Some economic work activities that school pupils are usually involved in constitute street hawking, farm work, illegal mining activities (galamsey) and extreme forms of domestic chores (those above the physical and mental abilities of children).Education is an important dimension of children's life (Santrock, 2003). Apart from the fact that children learn from their parents, their siblings, their peers, books, watching television and from the computers, they learn a lot in various levels of education. It may be observed that for a pupil or student to be successful in his or her academic performance, the pupil has to be regular in school, face learning problems squarely, avoid coming to school late and he or she should consult with the teacher. One of the major constraints in Ghana's growth challenge has been the lack of human capital development and basic school education is a contributing factor to this. The rationale for this study is to assess the effects of child labour on the academic performance of pupils in basic schools in Ahafo Kenyasi of the Brong Ahafo Region of Ghana. Specifically, the study aimed at identifying the kinds of labour activitiesthat basic school pupils are engaged in,in Ahafo Kenyasi, and determine how child labour affects their academic life.

\section{Methodology}

The research adopted the case study design of the qualitative research approach to help gain an in depth understanding of issues concerning the concurrent roles of working and studying. Qualitative research helps in deep understanding of opinions of participants; down plays biases and subjective responses and possibly displays the needed level of empathy for proper understanding. The researchers used this approach because they wanted to get in depth data and responses about the experiences of pupils who are involved in economic work activities.

\subsection{Sampling}

For this particular study, the researchers adopted snowball sampling technique in selecting pupils involved in child labour within Ahafo Kenyasi. This method allowed the researchers to find one person who possessed the characteristics the researchers were looking for and this individual led them to other pupils who also worked and studied concurrently. This procedure was used until the researchers obtained 35 pupils involved in work activities.

\subsection{Instrument}

Semi-structured interview guide was used to collect data for the study. The researchers used semi-structured interview guide because it allowed the participants express themselves at length while preventing them from drifting off the issues under discussion. Semi-structured interview guide gave the researchers the opportunity to use probes and prompts as and when necessary to obtain data and stay focused on the subject matter.

\subsection{Data Analysis}

After all data had been collected through the interviews, they were analysed qualitatively using deductive thematic data analysis approach. Thematic analysis allowed the researchers to organise the data, transcribe it, group it under preset themes and code it to help the researchers identify consistencies and inconsistencies. Organizing data was done with careful consideration of confidentiality and anonymity of the participants and dates, names, time and place of interview. This was followed by transcription and then themes were generated in line with patterns evolving from the literature. Coding was done by putting identified text segments in brackets and assigning a code made up of letters and numbers. This gave a precise meaning to text segments. Serial numbers were given to 35 interviewees in the order of PCW01 - PCW35 (P - Participant, C- Child, W - Worker).

The text segments were aggregated under the following dominant themes:

- Forms of work engaged in by pupils in Ahafo Kenyasi.

- Reasons why pupils work and study in tandem in Ahafo Kenyasi

- Effects of concurrent roles of working and studying on the academic life of pupils in Ahafo Kenyasi.

\section{Results and Discussion}

\subsection{Forms of Work Engaged in by Pupils}

Forms of child labour constitute the various labour activities undertaken or engaged in by basic school children in Ahafo Kenyasi. Responses given by interviewees are analyzed below.

\subsection{Forms of Work Done by Pupils in Ahafo Kenyasi}

The forms of child labour in Ahafo Kenyasi refer to the different kinds of labour activities that children engage in side by side their education. Our study discovered that hawking, petty trading and child farming are the major forms of work children do in Ahafo Kenyasi.

Some responses given by participants during interviews are as follows:

"I carry local rice on my head and roam through town until I have been able to sell it all". PCW 06

"When I get home after school, I sell phone recharge cards. It is situated just in front of our house and I sit by it till evening time. I also help my parents on the farm often". PCW 02 
"Immediately I close from school, I rush to the house, change my clothing and go to the market to sell chilled water. On non-market days, I carry some of it on my head and roam through the town". PCW 22

In the evening, I sell fried eggs, bread and iced water just in front of our house till about 11:00 pm before I go to bed". PCW 30.

Although majority of the respondents did not indicate illegal mining and shop keeping as kinds of child labour, these activities are considered very relevant since some participants mentioned them among other activities as workactivities,they are engaged in to make a living. Other work activities mentioned were palm oil making, bicycle repairs and 'chop bar' operations.

\subsection{Reasons why Pupils Work and Study in Tandem in Ahafo Kenyasi}

The causes of child labour refer to the factors that lead children into labour activities while they go to school. Some of the causes that evolved from our study were low family income, large family size, absence of father, unemployed parent(s) and illiteracy of parents. Students were asked why they engage in the particular economic activity they have mentioned during interviews. Here are some of their responses:

"My mother says that her money is not enough to cater for our education and so I should sell corn dough so that when she gets money, she will top it up with what I get from the corn dough. This will help her to pay our school fees and buy for us petty things we need for school". PCW19

"I am the eldest child and we are six children. My father is not around and my mother works as a pipe (stand pipe) tender in our area. She told me that the money she gets from the water business is not enough and so I should try and work so that when I get some, she will add hers to it. That is why I work as a bicycle repairer after school". PCW 07

"My father says he has no money to cater for me and my other siblings. My mother is also jobless and so I always go to the 'galamsey' (mining) site to carry load so that I get money to pay my school fees and other things". PCW 16

One of the children stated that he helped his mother with her work activity due to her health condition. He said:

"My mother is asthmatic and so as the eldest child, I have to help her with cleaning of the utensils and carrying of the heavy cooking pots that she prepares the rice she sells in before I come to school every morning and after school in the afternoon". PCW 17

The findings above seem to suggest that inadequate parental income is a major cause of child work. This confirms writings of scholars such as (Galli, 2001). According to him, children are sent to work when parents' earnings are insufficient to guarantee the survival of the family, or are insecure so that working and studying in tandem is used as a means of minimizing the impact of possible job loss, failed harvest and other shocks on the family's income stream. It also confirms the luxury axiom of altruistic models of child labour which states that in a situation where the family's level of income falls below a point where it cannot cater for the whole family, children would have to be sent to work in order to supplement the family's income (Basu \& Van, 1998).

\subsection{Effects of Child Labour on Children's Academic Life}

Here, the researchers looked at the adverse effects of working on children's education in terms of regularity, punctuality, time for learning and doing homework and levels of concentration. Through the interviews,the pupils revealed that working to earn a living affects their academic life. Below are some of their responses:

"When I come to school in the morning, I sometimes feel sleepy and so I do doze off in class. On days that we make palm oil, I feel pains all over my body when I come to school”. PCW 09

"Because we don't close from the chop bar early, I sleep very late. Because of that I am not always able to do my homework in the evening. We still have to wake up at dawn and prepare the work place before I come to school and so by the time, I come to school I will be tired already. When our teacher comes to class, I always feel like sleeping". PCW 35

"I do my homework all the time but I always do it at where I sell the oranges. There is a street light there so as we are sitting by the oranges, I will be doing it. If I don't do that, I won't get the chance to do it again because I sweep our compound and dispose off the rubbish before I come to school. Our teachers have told us not to come and do our homework here in school so I do it at home". PCW 20

"On days that I don't have money to go to school and my mother doesn't have money; I go to the bicycle repairs shop to work there so that the next day, my master will give me some money to go to school. It is usually on Thursdays that I intentionally miss school. This is because it's a market day and most of the village dwellers bring their bicycles for repairs. This enables me to get more money for the next day". PCW 07

"There have been days that because of my mother's items-to-be-sold, I don't come to school. Even last two weeks, I didn't come because she said she was going for a funeral and so I should watch the items for her". PCW 28

From the above, it is clear that child labour does have some negative consequences on the academic life of students. Again, all the above responses fall in line with Khanam and Ross (2005) who posited that child labour might impede school attendance and the quality of learning achievements of children. Also, Stein and Soderman (1998) found out that working while in school can lead to lower grades, less time spent on homework, increased likelihood of dropout and lower likelihood of entering school education. 


\section{Conclusion}

Based on the findings of this study, it can be concluded that the major form of child labour among basic school children in Ahafo Kenyasi is petty trading and hawking. There are however other forms of labour that children engage in such as bicycle repairs, farming and illegal mining (galamsey).

Also, labour activities among basic school children in Ahafo Kenyasi have some negative effects on the school going child. The major effects are fatigue, tiredness and poor concentration in class, and limited time to study and do assignments brought home from school. Other effects are absenteeism and poor academic achievement, school dropout and regular class repetition.

\section{Recommendations}

Based on the findings of the study, the following recommendations were made:

- There is the need to create awareness to parents on the relevance of their children's education and dangers of child labour on their children. The first point of call could be the Parent Teacher Association in various schools.

- Apart from their regular activities, circuit supervisors of Ahafo Kenyasi should be tasked to interrogate teachers and pupils on the child labour issues. This will enable the District Education Directorate devise appropriate strategies to reduce it drastically, if not totally erase child labour in Ahafo Kenyasi.

- Scholarship schemes should be established. This would help prevent parents from pushing their children into labour activities because of their education and in turn reduce the rate of child labour since it has been found that low family income is a major cause of child labour.

- Activist groups such as the Commission for Human Rights and Administrative Justice (CHRAJ) should be equipped to embark on vigorous sensitization programmes to help reduce child labour in Ahafo Kenyasi.

\section{References}

i. Basu, K., \& Van, P. H. (1998). The economics of child labor. American economic review, 412-427.

ii. Bhalotra, S., \& Heady, C. (2003). Child farm labor: The wealth paradox. The World Bank Economic Review, 17(2), 197-227.

iii. Galli, R. (2001). The Economic Impact of Child Labour. Geneva.

iv. Ghana Statistical Service. (2014). Ghana Living Standard Survey Round 6. Accra. Retrieved from http:/ / webdeploy.statsghana.gov.gh/ gssmain/ fileUpload/ Living conditions/ GLSS6_Main Report.pdf

v. Holgado, D., Maya-Jariego, I., Ramos, I., Palacio, J., Oviedo-Trespalacios, Ó., Romero-Mendoza, V., \& Amar, J. (2014). Impact of child labor on academic performance: Evidence from the program "Edúcame Primero Colombia." International Journal of Educational Development, 34, 58-66. https:/ / doi.org/ 10.1016/ J.IJEDUDEV.2012.08.004

vi. International Labour Organization (ILO), (2010). Accelerating action against child labour. Global report under the follow up to the ILO declaration on fundamental principles and rights at work. Retrieved 15-11-2016 from http:/ / www.books.google.co.ke.

vii. Khanam, R., \& Ross, R. (2005). Child Work and Other Determinants of School Attendance and School Attainment in Bangladesh. MPRA Paper No. 9397, Munchen.

viii. Kostelnick, M. J., Stein, L. C., Whiren, A. P., \& Soderman, A. K. (1998). Guiding children's social development. Albany. Ny: Delmar.

ix. Orazem, P. L., \& Gunnarsson, V. (2004). Child labour, School attendance, children, And performance. A review working paper (No. 04001). Iowa.Retrieved from http:/ / econ2.econ.iastate.edu/research/ webpapers/ paper_11177_04001.pdf

x. Santrock, J. (2003). Children. (7th Ed.). United States: University of Texas Dallas, McGraw-Hill Publishers. 